\title{
SAFETY MANAGEMENT OF WATER ECONOMY. CASE STUDY OF THE WATER AND SEWERAGE COMPANY
}

\author{
Janusz KARWOT \\ Sewage and Water Supply Ltd. Rybnik \\ Józef OBER \\ Silesian University of Technology
}

\begin{abstract}
:
This study addresses the issues of water management safety management in the context of shaping the appropriate level of municipal services in Poland, related to quality standards and the availability of water resources for enterprises and the local community. The literature review presents examples of activities concerning the evaluation of the quality and availability of groundwater and their suitability for domestic and commercial use in the world. The key parameters of water intended for human consumption, which affect its quality, have been selected based on the literature and the Polish standards set out in the regulation. On this basis, appropriate parameters for case-study research were selected. In the following, the analytical methods and tools used to assess water quality were characterized. In the case study example, the analysis of water parameters from selected three different intakes in 2015-2017 (Tęczowa, Stodoły and GPW Rybnik-Północ) was performed and the functioning and role of the internal Water and Sewage Laboratory in the safety management of water economy in the water and sewerage company has been presented.
\end{abstract}

Key words: water economy, water quality, water and sewerage company, safety management

\section{INTRODUCTION}

Poland is a country with relatively small water resources. They are around $1580 \mathrm{~m}^{3}$ per resident per year. In periods of drought in the country, the index drops even below $1000 \mathrm{~m}^{3}$ per person per year. As a comparison, the average water resources per resident of Europe are about $4560 \mathrm{~m}^{3}$ per year [9]. Human health (access to clean water), human safety (flood-prone areas), economic development (agriculture), the condition of the natural environment and the development of tourism and recreation [11], among others, depend on the appropriate quantity and quality of water resources. Opinions of water management practitioners are unanimous and underline the fact that water, which used to be a free good, has now become an economic good of both utility and commercial value as a result of growing human consumption [18]. This is one of the reasons why proper water management in our country seems to be so important.

Management sciences mostly concentrate on industries that are competitive on the global market, leaving the municipal sector outside the mainstream of interests. However, shaping the right level of municipal services is a prerequisite for the proper operation of enterprises and local communities [6]. It is worth noting that climate change, rapid urbanization and inadequate urban planning policies in many countries have caused problems with urban water, such as flood disasters, water pollution and water scarcity. An example can be China, where to solve these problems from 2013. A special urban water management strategy known as Sponge City has been implemented. The concept has four main principles: urban water resources, ecological water management, green infrastructure and urban permeable surface [14]. In the Polish literature you can also find examples of guidelines for activities for water and sewage sector companies. In the opinion of Cyfert, if the water supply company does not take proactive measures, the pace of its development will be slower than the development of the environment, which in the long run may lead to the collapse of the organization [7]. In turn, Bełz points out that when formulating the strategy of managing a water supply company one should take into account theoretical concepts, methods of assessing the maturity and experience and conclusions from the case study of water supply companies [3].

The aim of the article is to develop the guidelines that will be useful for executives in continuous water safety management. In addition, the authors aim to indicate the methods applicable for building the strategy of water and sewage entity. 
In order to achieve the goal, analysis of selected water parameters in several intakes over a three-year period has been made and the way of functioning and the role of the internal Water and Wastewater Laboratory in managing the safety of water management in the water and sewage company are presented. The case study is based on PWiK Rybnik.

\section{LITERATURE REVIEW}

Water management is a system management that covers all aspects of water demand and quality. An important role in water management is played by the state authorities: the Ministry of the Environment, water management boards, voivodship boards, poviats, communes and citizens [16]. Water management in a water and sewerage company is a part of the water cycle in nature, from water intake to return to the environment as treated sewage. Research indicates that any environment close to industrial activities faces major challenges related to water contamination. Armer and Carstens draw attention to the need to map water quality along with the identification of potential contaminants by means of satellite images and historical data collection on water quality. According to the authors, the key parameters of water quality are: nitrogen, phosphorus, coliforms and dissolved oxygen [5]. Gupta and Misra points out that the quality of groundwater is contaminated mainly for two reasons. One of them is the addition of pollutants as a result of anthropogenic activity (called anthropogenic pollution), and another is pollution caused by the presence of natural minerals in the aquifer [8].

Leveque, together with Burns [12] point out that in the context of numerous and diverse water crises around the world, water quality has become a major problem in the management of natural resources, which have a significant impact on the population and change the social perception of tap water quality. According to Alcamo, good water quality is of global importance and makes an essential contribution to ecosystem services such as drinking water, cooking water, industrial water, hygienic water, safe use of surface water for recreational purposes, fishing and others. The author conducted research on the basis of which indicates a general link between economic growth and water quality. He presents a correlation between the increase in the total released volume of untreated or partially treated sewage and the increase in economic indices to a certain level. In addition, he shows a link between the increase in water quality and an improvement in the efficiency of natural resources (as less materials per service are used with the increase in efficiency). There is also a link between water quality and trade, as trade involves the relocation of economic activities with undefined water contamination and other environmental impacts [1]. Similar views are presented by Portuguese scientists, who stress that improving groundwater quality will bring direct benefits to society and groundwater ecosystems. The research carried out indicates that public understanding of the social value of groundwater protection is still limited. This is partly due to the invisible and intangible nature of groundwater resources and the lack of research on the valuation of these resources [4].

One example of a research in terms of assessment of the groundwater quality and suitability for domestic use worldwide is the research in the area of suburban settlements in Zimbabwe, where eighty groundwater samples were collected monthly from January to April 2017. They were analysed in terms of physicochemical and microbiological parameters including temperature, turbidity, $\mathrm{pH}$, electrical conductivity, dissolved oxygen, chlorides, nitrates, phosphates and coliforms. The water quality index (WQI) was defined, by means of which the suitability of groundwater for drinking was determined [13].

Similar research has also been carried out in India, where particular attention is paid to the development of green areas, due to their beneficial effects on the health of residents. The maintenance of such areas is directly related to the quality of groundwater. The quality of 25 groundwater samples in Rourkela city was assessed from March to May 2017 on their suitability for irrigation purposes in order to maintain green areas in the city. The assessment took into account $\mathrm{pH}$, electrical conductivity, total hardness, sodium absorption coefficient, residual soluble carbonate, residual sodium bicarbonate, permeability index, potential salinity and magnesium hazard [2].

Another example of groundwater quality monitoring research is the Pakistan province of Balochistan. In this case, groundwater quality was assessed on the basis of 22 physicochemical parameters. Thirty water samples were taken from different locations in the studied area. The samples were collected in two separate polyethylene bottles, one used for anion analysis and other physicochemical parameters, while the samples from the second bottle were slightly acidified to reduce chemical variability, adsorption and precipitation, and to remain dissolved in aqueous solution by the metal ions. Samples of acidified water were used to analyse various traces of heavy metals and light metals. PH-meter (Model 6230N, JENCO), TDS meter (EuTech, CON 11, Singapore) and E.C. meter were used for the research. (EuTech, CON 11, Singapore). $\mathrm{K}^{+}$and $\mathrm{Na}^{+}$ were measured with a flame photometer (DN7101, Italy), while $\mathrm{Cl}^{-}$and $\mathrm{HCO}_{3}$ were measured by titration method (APHA, 1992). SO42 was determined with SulfaVer4 using a UV spectrophotometer (Hach-8051). Fluorine was assessed using an ionic selective electrode (CRISON, GLP $22+$ ). Arsenic (As) and mercury ( $\mathrm{Hg}$ ) were assessed using a flame atomic absorption spectrophotometer (220 Spectra $A A$, Varian), while other metals were assessed using an atomic absorption spectrophotometer (AA-7000 Shimadzu). The research showed that the water was of poor quality for drinking purposes. The degree of sodium absorption, residual sodium carbonate, percentage of sodium and permeability were assessed, in terms of suitability of groundwater for irrigation purposes. In addition, it was found that groundwater was suitable for irrigation purposes only in terms of sodium absorption coefficient and permeability index. It was concluded that remedial measures were urgently needed to protect the health of 
the local population depending on the use of contaminated groundwater in the examined area [10].

Another example of groundwater quality studies is northeastern Algeria. In this case, the aim was to monitor groundwater quality in order to understand how local and natural conditions affect water resources over time. Seventy-one groundwater samples were collected and analysed from drinking wells through four measurement campaigns in 2001, 2006, 2009 and 2010. Algeria is currently one of the Mediterranean countries most exposed to water scarcity, which is why the sustainable use of this resource is very important and, together with its scarcity, its quality is deteriorating. In this case, physical and hydrochemical analyses focused on the following issues: electrical conductivity (EC), $\mathrm{Ca}^{2+}, \mathrm{Mg}^{2+}, \mathrm{Na}^{+}+\mathrm{K}^{+}, \mathrm{Cl}^{-}, \mathrm{SO}_{4}{ }^{2-}$ and $\mathrm{HCO}_{3}{ }^{-}, \mathrm{NO}_{3}{ }^{-}$. Before each sample was collected, it was necessary to pump to remove the standing water stored in the enclosure column. Water was filtered and poured into polyethylene bottles. Conductivity was measured on site and other parameters were measured after transfer to the National Enterprise of Iron laboratory in Tebessa [20]. In Poland, legislation aimed at the health of present and future generations requires the control of the supply of water for human consumption as well as "used water", i.e. treated sewage disposed to the receiver and returned back to the environment. It should be emphasised at this point that not only quality is the subject of the water and sewerage company's activity, but also, and perhaps above all, ensuring the continuity of water supply and sewage disposal. Sewage and Water Supply Ltd. Rybnik consistently implements its strategy of ensuring the security of water supply at the highest level by providing a multidirectional and multi-point supply system from various sources, both own and external suppliers. Sewage and Water Supply Ltd. Rybnik provides water supply and sewage disposal services in the area of three communes: Rybnik, Jejkowice and Gaszowice. In total, it operates 1149.3 $\mathrm{km}$ of water supply network and $857.4 \mathrm{~km}$ of sewerage network. Water supplied to customers of Sewage and Water Supply Ltd. Rybnik comes from three sources: $76 \%$ is taken from the main network of Górnośląskie Przedsiębiorstwo Wodociągów S.A., 17\% from Ujęcia Elektrowni Rybnik S.A. in Stodoły, and 7\% from two independent intakes. The first one is Tęczowa, located in the centre of the Rybnik city. The second one is located in the RybnikBoguszowice district, where a new water treatment plant based on an innovative membrane water treatment technology was established. Therefore, the water supplied comes both from the GPW surface intakes and deep wells, which significantly increases the level of safety and guarantees the reliability of supplies.

\section{METHODOLOGY OF RESEARCH}

On the basis of the structure of supply from individual water sources, 50 fixed points were identified, which allow for water quality control in the whole area of operation of Sewage and Water Supply Ltd. Rybnik. More than 1000 water samples in the basic physicochemical and bacteriological range (Parameters of group A) are controlled an- nually by the company's laboratory. The Sewage and Water Supply Ltd. Rybnik Laboratory works on certified materials and reliable new equipment, and the analysis process is constantly monitored. The basic equipment used in the physicochemical analysis of water include MERCK Spectroquant Prove 100 spectrophotometer (year of manufacture 2016) for determination of dissolved matter concentrations in the analytical sample, turbidimeter TL 2310 LED (year of manufacture 2017) from HACH for determination of turbidity, laboratory meter from $\mathrm{HACH}$ multi-parameter two-channel HQ440d multi (year of manufacture 2014) for simultaneous determination of $\mathrm{pH}$ and conductivity, and Tirette digital burette from BRAND company for titration analyses. Each device has a "Device Card", where all servicing, checks, inspections, calibrations and repairs are recorded. Analyses are performed with both standardised methods and finished spectrophotometric tests. The scope of control includes both the analysis of physicochemical and bacteriological parameters. The scope of water analysis is presented in Table 1.

Table 1

The list of parameters indicated in the samples of tap water, performed by the Laboratory of Sewage and Water Supply Ltd. Rybnik

\begin{tabular}{|c|c|c|c|}
\hline No. & $\begin{array}{c}\text { Name } \\
\text { of designation }\end{array}$ & Unit & Test method \\
\hline 1 & Turbidity & NTU & Nephelometric \\
\hline 2 & Colour & $\mathrm{Hz}$ & spectrophotometric \\
\hline 3 & Odour/Taste & & Organoleptic \\
\hline 4 & Reaction & $\mathrm{pH}$ & Electrometric \\
\hline 6 & Conductivity & $\mu \mathrm{sm}$ & Electrometric \\
\hline 7 & Ammonia & $\mathrm{mg} / \mathrm{l}$ & spectrophotometric \\
\hline 8 & Nitrates & $\mathrm{mg} / \mathrm{l}$ & spectrophotometric \\
\hline 9 & Nitrites & $\mathrm{mg} / \mathrm{l}$ & spectrophotometric \\
\hline 10 & Iron & $\mathrm{mg} / \mathrm{l}$ & spectrophotometric \\
\hline 11 & Manganese & $\mathrm{mg} / \mathrm{l}$ & spectrophotometric \\
\hline 12 & Free chlorine & $\mathrm{mg} / \mathrm{l}$ & spectrophotometric \\
\hline 13 & Hardness & $\mathrm{mg} / \mathrm{l}$ & Titratable \\
\hline 14 & Chlorides & $\mathrm{mg} / \mathrm{l}$ & Titratable \\
\hline 15 & Alkalinity & $\mathrm{mg} / \mathrm{l}$ & Titratable \\
\hline 16 & $\begin{array}{l}\text { Coliforms, Escherichia coli } \\
\text { in } 100 \mathrm{ml} \text { of water }\end{array}$ & cfu & membrane filter method \\
\hline 17 & $\begin{array}{l}\text { Total number of bacteria } \\
\text { at } 37^{\circ} \mathrm{C} \text { in } 1 \mathrm{ml} \text { of water }\end{array}$ & cfu & pour plate method \\
\hline 18 & $\begin{array}{l}\text { The total number of bac- } \\
\text { teria at } 22^{\circ} \mathrm{C} \text { in } 1 \mathrm{ml} \text { of wa- } \\
\text { ter }\end{array}$ & $\mathrm{cfu}$ & pour plate method \\
\hline 19 & $\begin{array}{l}\text { Clostridium perfringens } \\
\text { (including spores) in } 100 \\
\text { ml of water }\end{array}$ & $\mathrm{cfu}$ & membrane filter method \\
\hline 20 & \begin{tabular}{|l|}
$\begin{array}{l}\text { Enterococcus in } 100 \mathrm{ml} \text { of } \\
\text { water }\end{array}$ \\
\end{tabular} & $\mathrm{cfu}$ & membrane filter method \\
\hline
\end{tabular}

Source: own study based on data from Sewage and Water Supply Ltd. Rybnik.

When measuring turbidity, a sample of water colored with dissolved substances weakens the radiation passing through the sample. Measurement using an optical turbidimeter, reading directly from the scale of the instrument (PN-EN ISO 7027-1:2016-09). 
The Hazen color unit $(\mathrm{Hz})$ corresponds to the intensity of the color of the solution containing $1 \mathrm{mg}$ Pt in $1 \mathrm{dm}^{3}$. Photometric measurement, reading from the scale of the instrument.

The qualitative assessment of the aroma and taste consists in the organoleptic determination of the type of aroma and taste, and then qualifying it to one of the groups given in the norm (PN-EN 1622:2006).

The $\mathrm{pH}$ determination consists in measuring the electromotive force of the cell in the reference electrode system - water sample - measuring electrode. Measurement using a probe with electrodes, reading from the scale of the instrument (PN-90 C-04540/01:1990).

The electrical conductivity is a measure of the current conducted by the ions present in the water. Measurement using a probe with electrodes, reading from the scale of the instrument (PN-EN 27888:1999).

Ammonium nitrogen is partly in the form of ammonium ions and as ammonia. There is a pH-dependent balance between the two forms. In strongly basic solutions, the ammonium nitrogen is in the form of amoaniac, which reacts with the chlorinating agent to form monochloramine. This, in turn, reacts with thymol to form a blue-colored derivative of indophenol, which is determined photometrically (Merck 1.14773.0001).

Nitrates react in a solution acidified with sulfuric and phosphoric acid with 2.6 - dimethylphenol to form an orange solution of $4-$ nitro -2.6 - dimethylphenol, which is determined photometrically (Merck 1.09713.0001).

In an acidic solution, the nitrite ions react with the sulfanilic acid to form a diazonium salt, which in turn reacts with $\mathrm{N}-(1$ - naphthyl) ethylenediamine dihydrochloride to the red - purple form of the azo dyes. The resulting dye is determined photometrically (Merck 1.14776.0001).

All iron ions are reduced to the divalent form (II). In solution buffered with thioglycolate, iron (II) ions react with the triazine derivative to form a red - purple complex determined photometrically (Merck 1.14761.0001).

In the basic solution, manganese ions (II) react with oxime to form a red - brown complex, which is determined colorimetrically (Merck 1.14770.0001).

In a slightly acidic solution of acetate buffer, aluminum ions react with the reagent Chromazurol $\mathrm{S}$ to form a blueviolet compound, which is determined photometrically (Merck 1.14825.0001).

In slightly acidic solutions, free chlorine reacts with dipropyl p-phenyldiamine (DPD) to form a violet - red dye, which is determined photometrically (Hach Lange LCW 510).

Complexometric titration of calcium and magnesium with a free solution of EDTA disodium salt at $\mathrm{pH} 10$ in the presence of black mordant 11 as a colorant, causes a change from dark red to blue, which indicates the end point of the titration (PN-ISO 6059:1999).

The reaction of chlorides with silver ions leads to the formation of insoluble silver chloride that precipitates quantitatively. The introduction of a small excess of silver ions in the presence of chromate ions as an indicator creates a red - brown silver chromate, which indicates the end point of the titration (PN-ISO 9297).
Titration of the test sample with a standard solution of hydrochloric acid in the presence of methyl orange as a dye results in a change in the color of the sample from orange to pink, indicating the end point of the titration (PN EN ISO 9963-1:2001).

Quantification of Escherichia coli and coliform bacteria by membrane filtration. Incubation on Chromogenic Coliform Lab - Agar (PN-EN ISO 9308-1:2014-12).

The method of determining the total number of bacteria consists in introducing a known sample volume of water into Yeast Extract Lab - Agar and then incubating (PN-EN ISO 6222).

Quantification of vegetative cells and spores of Clostridium perfringens by membrane filtration. Incubation on Tryptose Sulfite Cycloserina Agar (TSC) in anaerobic conditions.

Quantification of fecal enterococci by membrane filtration. Incubation on Slanetz and Bartley Lab - Agar (PN-EN ISO 7899-2:2004).

\section{RESULTS OF RESEARCH}

For the purpose of this article, five key water quality parameters were selected. Figures 1 to 5 present a selected comparison of results of water samples measurements from three different intakes in the years 2015-2017: a well at ul. Tęczowa, SUW Stodoły and a selected supply point from GPW S.A. - Rybnik-Północ.

Figure 1 presents a comparison of water conductivity in the Tęczowa, Stodoły and GPW Rybnik-Północ intakes in 2015-2017.

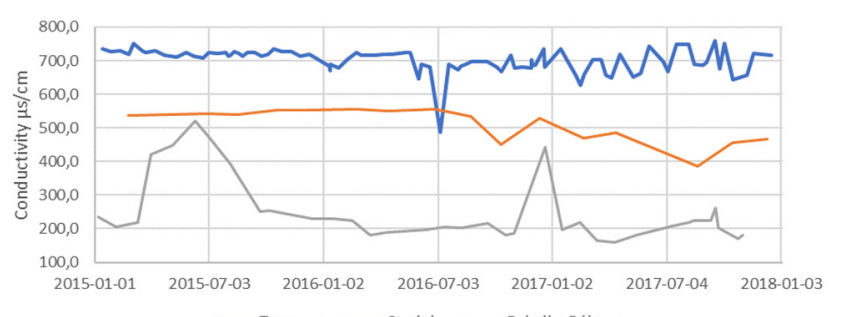

Fig. 1 The comparison of the results of measurements of water conductivity from three different intakes in the years 20152017

Source: own study based on data from Sewage and Water Supply Ltd. Rybnik.

Referring to the Regulation of the Minister of Health of 7 December 2017 on the quality of water intended for human consumption [17] - the recommended conductivity of such water should not exceed $2500 \mu \mathrm{S} / \mathrm{cm}$. The figure shows significant discrepancies in water conductivity depending on the intake and its greater fluctuations in the intakes of the GPW Rybnik-Północ and Tęczowa, with relatively high stabilisation of this parameter in the Stodoły intake. All three intakes in the period from 2015 to 2017 met the recommendations of the standard of the above mentioned regulation.

Figure 2 presents a comparison of the $\mathrm{pH}$ of water in Tęczowa, Stodoły and GPW Rybnik-Północ intakes in 2015-2017. 


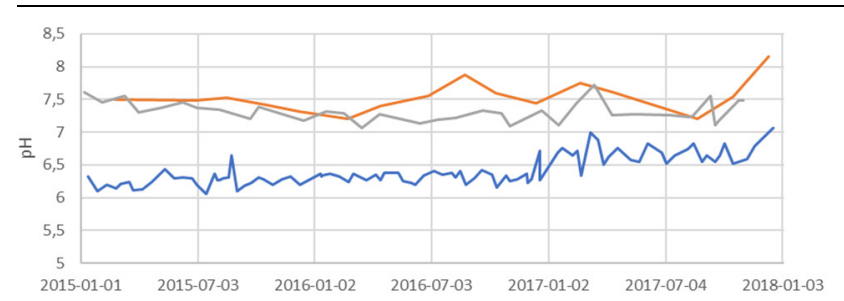

- Tẹczowa - Stodoły - Rybnik - Pótno

Fig. 2 The comparison of the results of $\mathrm{pH}$ measurements of water from three different intakes in the years 2015-2017 Source: own study based on data from Sewage and Water Supply Ltd. Rybnik.

Referring to the Regulation of the Minister of Health of 7 December 2017 on the quality of water intended for human consumption [17] - the recommended $\mathrm{pH}$ of such water should vary between 6.5 and 9.5. The figure shows a large discrepancy between the $\mathrm{pH}$ of water from the Tęczowa intake and very similar parameters from the Stodoły and the GPW Rybnik-Północ intakes. The $\mathrm{pH}$ of water from the Tęczowa intake in 2015-2016 is very slightly below the recommended standard; in 2017 its increase and maintenance of the parameters of the standard can be seen. The other two intakes in the period from 2015 to 2017 met the recommendations of the standard of the above mentioned regulation.

Figure 3 presents a comparison of the water colour in the Tęczowa, Stodoły and GPW Rybnik-Północ intakes in 2015-2017.

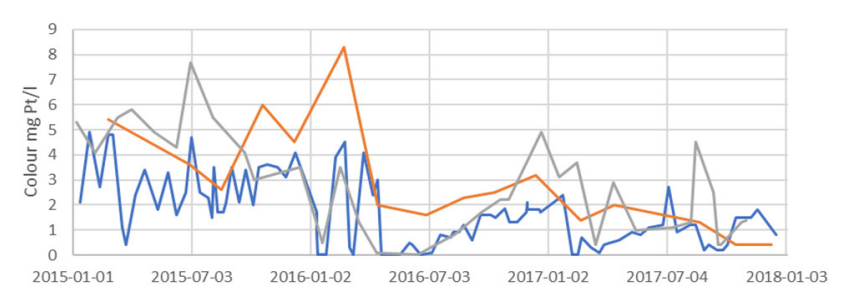
—Tęczowa —-Stodoły Rybnik- Północ

Fig. 3 The comparison of the results of measurements of the water colour from three different intakes in the years 20152017

Source: own study based on data from Sewage and Water Supply Ltd. Rybnik.

Referring to the Regulation of the Minister of Health of 7 December 2017 on the quality of water intended for human consumption [17] - the recommended colour of such water should be acceptable to customers and without incorrect changes (in the old regulation of 2007 the standard was not more than $15 \mathrm{mg} \mathrm{Pt/l).} \mathrm{The} \mathrm{figure} \mathrm{shows} \mathrm{slight}$ discrepancies in water colour depending on the intake, with slightly higher temporary values in the Stodoły and Rybnik-Północ intakes. All three intakes in the period from 2015 to 2017 met the recommendations of the standard of the above mentioned regulation and the older act, where the standard was more precisely specified.

Figure 4 presents a comparison of the water turbidity in the Tęczowa, Stodoły and GPW Rybnik-Północ intakes in 2015-2017.

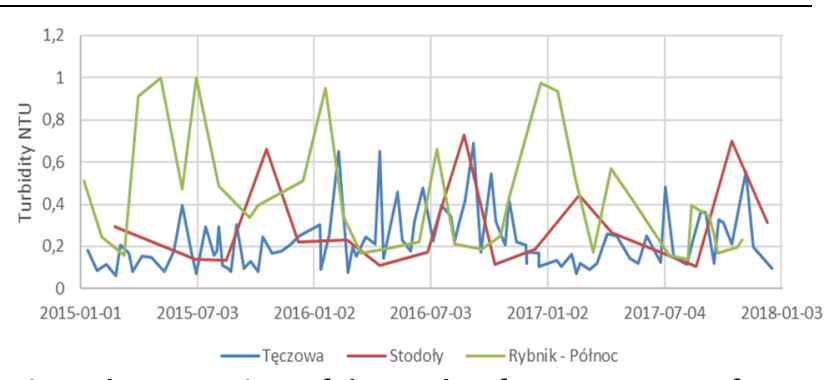

Fig. 4 The comparison of the results of measurements of water turbidity from three different intakes in the years 2015-2017 Source: own study based on data from Sewage and Water Supply Ltd. Rybnik.

Referring to the Regulation of the Minister of Health of 7 December 2017 on the quality of water intended for human consumption [19] - the recommended turbidity of such water should not exceed 1.0 NTU. The figure shows a large discrepancy between the turbidity of water from the intake of the GPW Rybnik-Północ and very similar parameters from the intakes of Stodoły and Tęczowa. Despite the momentary upper values of the standards from the GPW Rybnik-Północ intake, all three intakes in the period from 2015 to 2017 met the recommendations of the standard of the above mentioned regulation.

Figure 5 presents a comparison of the water hardness in the Tęczowa, Stodoły and GPW Rybnik-Północ intakes in 2015-2017.

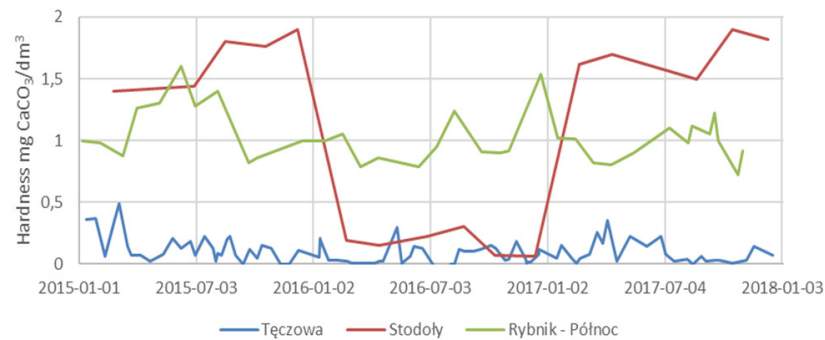

Fig. 5 The comparison of the results of measurements of the water hardness from three different intakes in the years 20152017

Source: own study based on data from Sewage and Water Supply Ltd. Rybnik.

Referring to the Regulation of the Minister of Health of 7 December 2017 on the quality of water intended for human consumption [19] - the recommended hardness of such water should range between 60-500 $\mathrm{mg} \mathrm{CaCO}_{3} / \mathrm{dm}^{3}$. However, this hardness is recommended for health reasons, i.e. it is a value desired for human health, but the regulation does not provide for the obligation to supplement it to the minimum value by a water supply and sewerage company. The figure shows significant discrepancies in water hardness depending on the intake and generally low hardness values in relation to the recommendations required for human health.

\section{DISCUSSION}

Regardless of its origin, in Poland tap water must meet the parameters of water intended for human consumption specified in the Regulation of the Minister of Health of 7 December 2017 [17]. An irreplaceable control tool is our own water supply laboratory which, knowing perfectly 
the layout of the network or the nature of sewage from the sewage treatment plant in operation, is able to properly interpret the results obtained and quickly undertake further procedural actions. It should be added that for daily diagnostics, in order to maintain the safety of water and sewage quality, the most important is the possession of appropriate equipment, personnel and compliance with the principles of good laboratory practice, not the accreditation certificates, which are actually required by control bodies. The control in Sewage and Water Supply Ltd. Rybnik is carried out by the internal Water and Sewage Laboratory. The laboratory has the necessary equipment and qualified personnel. Since 2005 it has been covered by the Integrated Management System functioning in the company, within the framework of which working procedures have been developed, supervision over equipment and measuring equipment has been implemented, individual processes functioning in the laboratory have also been described. Particular attention should be paid to the control system developed over the years. Control points were located in various areas of the water distribution system, i.e. in places where water was purchased from the GPW, on wells, then in pump rooms and designated points of the network and at consumers. The entire control system is included in internal, cyclically repeated water sampling schedules, meticulously implemented by the laboratory services of Sewage and Water Supply Ltd. Rybnik.

The analysis of the data provided is only a part of the controls carried out, but shows that diversification of supply from at least two or three sources is a necessary condition for ensuring safety. In addition, by fulfilling the provisions of the current regulation on the quality of water intended for human consumption, as well as the Act on collective water supply and sewage disposal [19], the laboratory employees implement an additional schedule of sampling in the quantity and scope approved by the local control body, i.e. The State District Sanitary Inspector in Rybnik. In this case, the role of the laboratory is limited to collecting water samples by employees trained in this field and transferring them to an independent, accredited external laboratory. The minimum frequency of collected water samples for testing in this case was calculated in accordance with Appendix no. 3 to the $\mathrm{RMH}$ and amounts to 63 analyses per year in the scope of monitoring group $A$ parameters and 10 analyses per year in the scope of monitoring group B parameters, which constitutes only $7 \%$ of analyses performed by the company laboratory. Reports with the results of analyses are sent to the Sanitary Inspectorate in Rybnik on an ongoing basis. Ordering analyses of water samples to a commercial laboratory is a kind of inter-laboratory comparison and constitutes an additional confirmation of the laboratory's reliability, thus confirming the legitimacy of conducting tests

Prior to the provisions of the new regulation, in which the control of the water supply system in taps for consumers, i.e. on internal installations is becoming obsolete, and it is preferred to locate the so-called "compliance points" on the distribution network located closest to the water meter, in 2016 laboratory employees initiated the installation of drain valves on water meters. The installation is carried out as part of the water meter replacement schedule. These valves make it possible to collect water samples for testing without the internal installation (without the need to dismantle the main water meter), which may be a source of secondary water contamination and may misrepresent the information on water quality in a given supply zone. In order to ensure the most effective protection of water quality in the company, a procedure was developed to ensure water supply in emergency conditions, and in this procedure the key role is played by the Sewage and Water Supply Ltd. Rybnik Laboratory. Since the company puts emphasis on transparency of the message, the results of the monitoring of the water supply network are continuously provided to the customers on the Sewage and Water Supply Ltd. Rybnik - http://www.pwik-rybnik.pl/laboratorium.html [15].

Thanks to such a system of control and distribution of water, the company is able to quickly diagnose possible irregularities in the network and take appropriate corrective and preventive measures, which, with a well-functioning management system, ensures the highest degree of safety and stability of water parameters in the network and the continuity of supply. It should be emphasised that the internal laboratory, if necessary, leaves to collect samples immediately without unnecessary procedures, orders or service orders, which, if commercial laboratory services were used, would be impossible and would certainly extend the response time considerably. Knowledge of the network allows laboratory employees to immediately recognise disturbing fluctuations in parameters and transmit information to the operating department, which is not only the recipient of information but also commissions a number of analyses to the company's laboratory, such as: physical, chemical and bacteriological control of newly built sections of the water supply network, control of water parameters after removing failures, effectiveness of preventive chlorination of the network in summer periods and finally by interpreting the parameters obtained helps resolve the source of leaks on the network and thus contributes to minimising water losses.

Carefully tested, safe for consumers, water goes to taps, and soon used water is returned to the water supply company's sewerage system as sewage. In Sewage and Water Supply Ltd. Rybnik the target point is the sewage treatment plant in Rybnik-Orzepowice, which is a key facility implementing circular management through, inter alia, sewage treatment.

In order to ensure proper quality of sewage disposed back to the environment, the Sewage and Water Supply Ltd. Rybnik Laboratory begins the control of the whole process by analysing the raw sewage flowing into the treatment plant, then, if necessary, after particular stages of treatment and finally treated sewage discharged into the receiver. Apart from the quality of sewage and sewage 
sludge, the laboratory also conducts analyses for the needs of calibration of measuring equipment and technological settings of equipment used at the treatment plant. The scope of sewage analyses performed by the company's laboratory is presented in Table 2.

Table 2

The list of parameters indicated in the samples of sewage performed by the Sewage and Water Supply Ltd. Rybnik

Laboratory

\begin{tabular}{|c|l|c|c|}
\hline No. & Name of designation & Unit & Research method \\
\hline 1 & Ammonia & $\mathrm{mg} / \mathrm{l}$ & Spectrophotometric \\
\hline 2 & Total nitrogen & $\mathrm{mg} / \mathrm{l}$ & Spectrophotometric \\
\hline 3 & Nitrates & $\mathrm{mg} / \mathrm{l}$ & Spectrophotometric \\
\hline 4 & Nitrites & $\mathrm{mg} / \mathrm{l}$ & Spectrophotometric \\
\hline 6 & Colour & $\mathrm{Hz}$ & Spectrophotometric \\
\hline 7 & BOD $_{5}$ & $\mathrm{mg} / \mathrm{l}$ & Titratable \\
\hline 8 & Chlorides & $\mathrm{mg} / \mathrm{l}$ & Spectrophotometric \\
\hline 9 & COD & $\mathrm{mg} / \mathrm{l}$ & Spectrophotometric \\
\hline 10 & Ether extract & $\mathrm{mg} / \mathrm{l}$ & Gravimetric \\
\hline 11 & Phosphorus & $\mathrm{mg} / \mathrm{l}$ & spectrophotometric \\
\hline 12 & Reaction & $\mathrm{pH}$ & electrometric \\
\hline 13 & Conductivity & $\mathrm{mg} / \mathrm{l}$ & electrometric \\
\hline 14 & Sulphates & $\mathrm{mg} / \mathrm{l}$ & $\begin{array}{c}\text { spectrophotometric ti- } \\
\text { tratable }\end{array}$ \\
\hline 15 & Solutes & $\mathrm{mg} / \mathrm{l}$ & Gravimetric \\
\hline 16 & Solid residue & $\mathrm{mg} / \mathrm{l}$ & Gravimetric \\
\hline 17 & Temperature & ${ }^{\circ} \mathrm{C}$ & electrometric \\
\hline 18 & Dissolved oxygen & $\mathrm{mg} / \mathrm{l}$ & electrometric \\
\hline 19 & Odour & & organoleptic \\
\hline 20 & Alkalinity & $\mathrm{mg} / \mathrm{l}$ & titratable \\
\hline
\end{tabular}

Source: own study based on data from Sewage and Water Supply Ltd. Rybnik.

Every year, about 156 extended analyses, not including individual determinations, are performed for the needs of the technology. All this to ensure that the treated sewage discharged into the environment is safe and meets the legal standards. As far as sewage management is concerned, this is not the end of the role played by the Sewage and Water Supply Ltd. Rybnik Laboratory. In accordance with the provisions of the Act on collective water supply and sewage disposal [19], the laboratory coordinates and controls industrial plants discharging sewage to the sewerage network of Sewage and Water Supply Ltd. Rybnik.

\section{CONCLUSIONS}

Summarizing the above considerations, it is worth noting that other methods with significantly lower ranges of quantification are also used in the water analysis, for example such methods include inductive excited mass spectrometry (ICP-MS) performed in accordance with PN-EN ISO 17294-2: in 2016. This method is applicable to the simultaneous determination of 62 elements in the test water sample. Parameters in water also use flow analysis methods (CFA, FIA) with spectrometric detection - PN-EN ISO 13395:2001. However, taking into account the analysis of water in terms of quality and suitability for domestic and commercial use, it seems that the methods presented in the case-study are completely sufficient and justified from an economic point of view.
Additionally, it is worth emphasizing that from the point of view of water management safety in a water and sewage company, parallel monitoring of selected water parameters in several intakes is one of the key elements of effective water management safety management. In connection with the above, it can be unequivocally stated that having a company laboratory is an essential tool for constant monitoring of water supply and sewage disposal, as well as for control and diagnostic activities. The laboratory operating only in its area can notice certain, even slightly changing parameters in order to take appropriate measures in time. It should be emphasised that the certificates or accreditation are not of great importance here, but first of all a harmonious, solid team and compliance with the principles of good laboratory practice, and most importantly, a sense of responsibility for the proper functioning of the company and the satisfaction of customers. One may also try to state that the developed model of activities presented in the article is a proven formula which can be applied in other companies with a similar profile of activity.

\section{REFERENCES}

[1] J. Alcamo. (2019, Feb.). „,Water quality and its interlinkages with the Sustainable Development Goals". Current Opinion in Environmental Sustainability. Vol. 36, pp. 126-140. DOI: 10.1016/j.cosust.2018.11.005.

[2] R. Barik, S.K. Pattanayak. (2019, Apr.). „Assessment of groundwater quality for irrigation of green spaces in the Rourkela city of Odisha, India". Groundwater for Sustainable Development. Vol. 8, pp. 428-438. DOI: 10.1016/j.gsd.2019.01.005.

[3] G. Bełz. „Kształtowanie nowoczesnego systemu zarządzania przedsiębiorstwem wodociągowym" in Zarzqdzanie przedsiębiorstwem wodociqgowym. Uwarunkowania funkcjonowania i współczesne koncepcje zarzqdzania. P. Chudziński, Ed. Warszawa: PWE, 2018, pp.185-202.

[4] R. Brouwer, C.M. Ordens, R. Pinto, M.T. Condesso de Melo. (2018, May). „Economic valuation of groundwater protection using a groundwater quality ladder based on chemical threshold levels". Ecological Indicators. Vol. 88, pp. 292304. DOI: 10.1016/j.ecolind.2018.01.041.

[5] D. Carstens, R. Armer. (2019, Feb.). „Spatio-temporal analysis of urban changes and surface water quality". Journal of Hydrology. Vol. 569, pp. 720-734. DOI: 10.1016/j.hydrol.2018.12.033.

[6] P. Chudziński. „Charakterystyka przedsiębiorstw wodociągowych w Polsce" in Zarzqdzanie przedsiębiorstwem wodociggowym. Uwarunkowania funkcjonowania i współczesne koncepcje zarzqdzania. P. Chudziński, Ed. Warszawa: PWE, 2018, pp.17-38.

[7] S. Cyfert. „Zarządzanie strategiczne i strategie” in Zarzqdzanie przedsiębiorstwem wodociqgowym. Uwarunkowania funkcjonowania i współczesne koncepcje zarzq̨dzania. P. Chudziński, Ed. Warszawa: PWE, 2018, pp. 135-150.

[8] R. Gupta, A.K. Misra. (2018, Mar.). „Groundwater quality analysis quaternary aquifers in Jhajjar District, Haryana, India: Focus on groundwater fluoride and health implications". Alexandria Engineering Journal. Vol. 57, pp. 375281. DOI: 10.1016/j.aej.2016.08.031.

[9] G. Kądzielawski. „Woda - palący problem”. Fede. Fundacja Energia dla Europy (Jan. 07, 2013). 
[10] Khanoranga, S. Khalid. (2019, Feb.). „An assessment of groundwater quality for irrigation and drinking purposes around brick kilns in three districts of Balochistan province, Pakistan, through water quality index and multivariate statistical approaches". Journal of Geochemical Exploration. Vol. 197, pp. 14-26. DOI: 10.1016/j.gexplo.2018.11.007.

[11] Z. Kundzewicz, M. Zalewski, A. Kędziora, E. Pierzgalski. (2010). „Zagrożenia związane z wodą”. Nauka. Vol. 4, pp. $87-96$.

[12] J.G. Leveque, R.C. Burns. (2019, Mar.). „Water quality perceptions and natural resources Extraction: A matter of geography?" Journal of Environmental Management. Vol. 234, pp. 379-386. DOI: 10.1016/j.jenvman.2018.11.126.

[13] F. Muzenda, M. Masocha, S.N. Misi. (2019, Feb.). „Groundwater quality assessment using a water quality index and GIS: A case of Ushewokunze Settlement, Harare, Zimbabwe". Physics and Chemistry of the Earth, Parts $A / B / C$. DOI: 10.1016/j.pce.2019.02.011.

[14] T.T. Nguyen, H.H. Ngo, W. Guo, X.C. Wang, N.Ren, G. Li, J. Ding, H. Liang. (2019, Feb.). „Implementation of a specific urban water management - Sponge City". Science of The Total Environment. Vol. 652, pp. 147-162. DOI: 10.1016/j.scitotenv.2018.10.168.

\section{Janusz Karwot}

Sewage and Water Supply Ltd. Rybnik Pod Lasem 62, 44-210 Rybnik, Poland e-mail: Karwotj@interia.pl ORCID ID: 0000-0002-5810-7535

\section{Józef Ober}

Silesian University of Technology

Organisation and Management Department

Roosevelta 26, 41-800 Zabrze, Poland

e-mail: Jozef.Ober@polsl.pl

ORCID ID: 0000-0001-6290-381X
[15] PWiK Rybnik. The Internet: www.pwik-rybnik.pl/laboratorium.html, [Nov. 27, 2018].

[16] E. Radzka, J. Jankowska. (2015). „Struktura organizacyjna i zarządzanie gospodarką wodną w Polsce". Zeszyty Naukowe Uniwersytetu Przyrodniczo-Humanistycznego w Siedlcach. Seria Administracja i Zarzqdzanie. Vol. 106, pp. 185-193.

[17] Regulation of the Minister of Health of 7 December 2017 (Dz. U. of 2017 item 2294).

[18] T. Strzelecki. „Zarządzanie wodami w oparciu o doświadczenie grupy SUEZ". Perspektywy i wyzwania gospodarki wodnej w świetle nowego prawa wodnego. Materiały pokonferencyjne. (Nov. 28, 2017), p. 17.

[19] Act on Collective Water Supply and Collective Sewage Disposal (Dz. U. of 2017 item 328).

[20] S. Zereg, A. Boudoukha, L. Benaabidate. (2018, Nov.). „Impacts of natural conditions and anthropogenic activities on groundwater quality in Tebessa plain, Algeria". Sustainable Environment Research. Vol. 28, Issue 6, pp. 340-349. DOI: 10.1016/j.serj.2018.05.003. 